\title{
FAKTOR-FAKTOR YANG MEMPENGARUHI KEJADIAN INFEKSI HIV PADA USIA PRODUKTIF DI KOMITE AIDS HKBP BALIGE
}

\author{
Rina Marlina Manalu, Sridama Yanti Harahap, Indah Sinurat \\ Program Studi D3 Keperawatan, STIKes Arjuna \\ E-mail: manaluurina23@gmail.com
}

\begin{abstract}
The number of cases of HIV infection in Indonesia reported up to June 2016, most cases occur in DKI Jakarta 41,891 cases in North Sumatra while the increase of 3,594 cases in the year 2014 be 5,184 cases in the year 2015 this is a global health problem that resulted in a number of events and figures the death toll dramatically. This study is an observational analytical study research design with case control, the population in this research is the whole of productive age are exposed to HIV infection in AIDS Committee HKBP Balige, amount of samples as many as 31 in the case group and 31 on the group control, the dwarf sampling namely accidental sampling. The results showed the factors that have an effect on the incidence of HIV infection is that there are influences of sex $(\mathrm{OR}=11,979 ; 95 \% \mathrm{CI}: 3.606-39.791)$, risky sex behavior $(\mathrm{OR}=12,815 ; 95 \%$ CI: 5.509-94.478)), the behavior of drug use $(\mathrm{OR}=10,175 ; 95 \% \mathrm{CI}: 3.893-51.607)$, and the most influential risk factors are behaviors of sex. The conclusions of the research are risk factors that influence the incidence of HIV infection is sex, sex risky behavior, the behavior of drug use. It is recommended that can plan a strategy for addressing the problem of HIV infection and prevent the factors that influence the incidence of HIV in the productive age Tobasa.
\end{abstract}

Key Word : Infection, HIV, Productive Age

\begin{abstract}
Abstrak
Jumlah kasus infeksi HIV di Indonesia dilaporkan hingga Juni 2016, sebagian besar kasus terjadi di DKI Jakarta 41.891 kasus di Sumatera Utara sedangkan peningkatan 3.594 kasus pada tahun 2014 menjadi 5.184 kasus pada tahun 2015 ini merupakan masalah kesehatan global yang mengakibatkan sejumlah peristiwa dan angka kematian secara dramatis. Penelitian ini adalah penelitian observasional analitik dengan desain case control, populasi dalam penelitian ini adalah seluruh usia produktif yang terpapar infeksi HIV di Komite AIDS HKBP Balige, jumlah sampel sebanyak 31 pada kelompok kasus dan 31 pada populasi. kelompok kontrol, sampling kerdil yaitu accidental sampling. Hasil penelitian menunjukkan faktor-faktor yang berpengaruh terhadap kejadian infeksi HIV adalah bahwa ada pengaruh jenis kelamin $(\mathrm{OR}=11.979$; 95\% CI: 3.60639.791), perilaku seks berisiko $(\mathrm{OR}=12.815$; 95\% CI: 5.509- 94.478)), perilaku penggunaan narkoba $(\mathrm{OR}=10.175 ; 95 \% \mathrm{CI}: 3.893-51.607)$, dan faktor risiko yang paling berpengaruh adalah perilaku seks. Kesimpulan dari penelitian ini adalah faktor risiko yang mempengaruhi kejadian infeksi HIV adalah jenis kelamin, perilaku berisiko jenis kelamin, perilaku penggunaan narkoba. Disarankan agar dapat merencanakan strategi untuk mengatasi masalah infeksi HIV dan mencegah faktor-faktor yang mempengaruhi kejadian HIV di usia produktif Tobasa
\end{abstract}

Kata Kunci : Infeksi, HIV, Usia Produktif 


\section{PENDAHULUAN}

Di era globalisasi ini Human Immunodeficiency Virus (HIV) dan Acquired Immune Deficiency Syndrome (AIDS) dianggap sebagai suatu penyakit yang mematikan dan merupakan masalah kesehatan global yang mengakibatkan jumlah angka kejadian dan angka kematian drastis selalu meningkat. HIV adalah epidemi yang sudah berkembang menjadi krisis global. Penyakit ini juga memiliki "window periode" dan fase asimptomatik (tanpa gejala) yang relatif panjang dalam perjalanan penyakitnya, hal tersebut menyebabkan pola perkembangannya seperti Fenomena Gunung Es atau iceberg phenomena (Hardisman , 2009).

HIV/AIDS merupakan penyakit menular yang disebabkan oleh infeksi Human Immunodeficiency Virus yang menyerang sistem kekebalan tubuh. Infeksi tersebut menyebabkan penderita mengalami penurunan ketahanan tubuh sehingga sangat mudah terinfeksi berbagai macam penyakit lain (Kemenkes RI, 2016). Tahap selanjutnya dari infeksi HIV adalah Acquired Immunodeficiency Syndrome (WHO, 2012). Menurunnya kekebalan tubuh mengakibatkan penderita sangat mudah terkena berbagai penyakit infeksi (infeksi oportunistik) yang sering berakibat fatal (Kemenkes RI, 2014).

Saat ini tidak ada negara yang terbebas dari masalah HIV/AIDS (Zein, 2006). HIV/AIDS pertama kali dilaporkan pada tahun 1981 di Atlanta, Amerika Serikat. Hampir satu juta orang di Amerika Serikat didiagnosa dengan AIDS selama 25 tahun pertama. Lebih dari setengah juta orang Amerika meninggal karena AIDS selama seperempat abad pertama epidemi, dan lebih dari 400.000 orang Amerika saat ini hidup dengan AIDS. Pada 2006, lebih dari 50.000 orang Amerika telah menjadi HIV+ (CDC. 2008). Namun, AIDS bukan hanya sebuah epidemi di Amerika Serikat. Penyakit AIDS ini adalah penyakit ditemukan di negara di seluruh dunia.

Tahun 2007, di Amerika berdasarkan data dari Penanggung jawab program HIV/AIDS (UNAIDS) terdapat 33 juta orang hidup dengan infeksi HIV/AIDS dimana 3 juta orang diantara terinfeksi HIV dan 2 juta orang meninggal karena penyakit tersebut (UNAIDS, 2012). Dalam Laporan United Nations Programme on HIV/AIDS (UNAIDS) pada tahun 2013 untuk HIV/AIDS di kawasan Asia dan Pasifik menyatakan Indonesia sebagai salah satu negara di kawasan Asia dengan peningkatan infeksi baru HIV/AIDS.

Pada tahun 2001 dan 2012 infeksi baru HIV/AIDS di Indonesia meningkat 2,6 kali. Perkiraan jumlah kasus HIV/AIDS di Indonesia menempati urutan ketiga setelah India dan China (UNAIDS, 2013). Berdasarkan UNAIDS Global Statistics (2014), penderita HIV/AIDS terbanyak berada di wilayah Afrika sebanyak 24,7 juta penderita. Sedangkan di Asia tercatat 4,8 juta penderita HIV/AIDS. Asia diperkirakan memiliki laju infeksi HIV tertinggi di dunia.

Berdasarkan data yang dirilis Kemenkes RI hingga September 2011, jumlah kasus HIV/AIDS mencapai total 17.394 kasus. Dengan rincian itu, penderita HIV dilaporkan sebanyak 15.589 kasus dan yang sudah positif AIDS sebanyak 1.805 kasus. Dari jumlah tersebut, sekira 88 persen penderita berasal dari kelompok produktif, dengan rentang usia 20-49 tahun, yang didominasi oleh free sex dan penyalahgunaan narkoba.

Penanggulangan HIV/AIDS di Indonesia tercantum dalam Peraturan Menteri Kesehatan Republik Indonesia Nomor 21 Tahun 2013. Adapun kegiatan penanggulangan HIV dan AIDS terdiri atas promosi kesehatan; pencegahan penularan HIV; pemeriksaan diagnosis HIV; pengobatan, perawatan, dan dukungan (PDP); dan rehabilitasi (Permenkes, 2013). Komite AIDS HKBP Kabupaten Tobasa merupakan salah satu komite yang menangani masalah HIV/AIDS serta menyediakan pelayanan khusus bagi penderita HIV/AIDS.

Kabupaten Tobasa merupakan salah satu kabupaten di provinsi Sumatera Utara dalam masa perkembangan maju. Dengan memiliki potensi industri yang cepat, objek 
wisata serta pertukaran ekonomi yang pesat membuat Kabupaten ini menjadi target para investor untuk berkunjung ke daerah tersebut. Dengan demikian hal itu dapat berdampak bagi pola struktur individu, masyarakat serta adanya zaman globalisasi dan sistem informasi dan komunikasi yang diterima masyarakat dapat bergaul dengan siapa saja.

Hasil wawancara dengan petugas kesehatan di komite AIDS HKBP bahwa penyebab usia produktif terkena AIDS adalah akibat melalui hubungan intim berisiko dengan lawan jenis (seks bebas) yang mencapai 81,3 \%; hubungan intim dengan sesama jenis $5,1 \%$; dan ibu yang mengidap HIV lalu menularkan pada anaknya mencapai $3,5 \%$; serta pengguna narkotika melalui jarum suntik 3,3\%, sebagian pasien yang berumur $>40$ juga tercatat terinfeksi HIV/AIDS baru melaporkan penyakitnya ke komite AIDS padahal mereka mengaku sudah sejak remaja terinfeksi HIV/AIDS. Dari jumlah penderita pasien HIV/AIDS di Toba Samosir diperoleh $28 \%$ penderita berasal dari anak rantau, dan memilih pulang kekampung karena malu hidup di luar daerah karena penyakit yang dideritanya sehingga dengan kedatangan mereka ke Toba Samosir menambah prevalensi penderita HIV/AIDS (Komite HIV/AIDS HKBP, 2017).

\section{METODE PENELITIAN}

Penelitian ini merupakan penelitian studi analitik observasional dengan desain case control, populasi dalam penelitian ini adalah seluruh usia produktif yang terkena infeksi HIV di Komite AIDS HKBP Balige, jumlah sampel sebanyak 31 pada kelompok kasus dan 31 pada kelompok control, tekhnik pengambilan sampel yaitu accidental sampling. Pengumpulan data dengan menggunakan kuesioner dan dianalisis dengan menggunakan uji Chi Square.

\section{HASIL DAN PEMBAHASAN}

Distribusi Frekuensi Responden

Berdasarkan Data Demografi di Komite AIDS HKBP Balige Desember 2017 (n=62)

\begin{tabular}{lcccc}
\hline $\begin{array}{l}\text { Karakteristik } \\
\text { Responden }\end{array}$ & \multicolumn{2}{c}{$\begin{array}{c}\text { Kasus } \\
(\mathbf{n}=\mathbf{3 1})\end{array}$} & \multicolumn{2}{c}{$\begin{array}{c}\text { Kontrol } \\
(\mathbf{n}=\mathbf{3 1})\end{array}$} \\
\cline { 2 - 5 } & $\mathbf{f}$ & $\mathbf{\%}$ & $\mathbf{f}$ & $\mathbf{\%}$ \\
\hline Umur & & & & \\
$17-35$ tahun & 12 & 38.7 & 16 & 51.6 \\
$36-55$ tahun & 19 & 61.3 & 15 & 48.4 \\
Jenis & & & & \\
Kelamin & & & & \\
Laki-laki & 25 & 80.6 & 23 & 74.2 \\
Perempuan & 6 & 19.4 & 8 & 25.8 \\
Pendidikan & & & & \\
Dasar & 1 & 3.2 & 2 & 6.5 \\
Menengah & 28 & 90.3 & 25 & 80.6 \\
Tinggi & 2 & 6.5 & 4 & 12.9 \\
Pekerjaan & & & & \\
Bekerja & 23 & 74.2 & 18 & 58.1 \\
Tidak bekerja & 8 & 25.8 & 13 & 41.9 \\
Status & & & & \\
perkawinan & & & & \\
Belum kawin & 8 & 25.8 & 4 & 12.9 \\
Sudah Kawin & 23 & 74.2 & 27 & 87.1 \\
\hline Jumlah & $\mathbf{3 1}$ & $\mathbf{1 0 0}$ & $\mathbf{3 1}$ & $\mathbf{1 0 0}$ \\
\hline
\end{tabular}

Berdasarkan tabel di atas diperoleh hasil penelitian pada karakteristik umur pada kelompok kasus mayoritas responden berumur 36-55 tahun sebanyak 19 responden $(87.1 \%)$ dan pada kelompok control mayoritas berusia 17-35 tahun sebanyak 16 responden (51.4\%). karakteristik jenis kelamin responden pada kelompok kasus dan control mayoritas berjenis kelamin laki-laki sebanyak 25 responden (80.6\%) dan 23 responden $(72.4 \%)$, Karakteristik pendidikan pada kelompok kasus dan control mayoritas berpendididkan menengah sebanyak 28 responden (90.3\%) dan 25 responden $(80.6 \%)$, karakteristik pekerjaan pada kelompok kasus mayoritas bekerja sebanyak 28 responden $(74.2 \%)$ dan 18 responden (58.1\%), karakteristik status perkawinan pada kelompok kasus dan control mayoritas sudah kawin sebanyak 23 responden $(72.4 \%)$ dan 27 responden $(87.1 \%)$. 
Faktor-faktor yang Memengaruhi Kejadian Infeksi HIV pada Usia Produktif di Komite HIV AIDS Balige $(n=62)$

\begin{tabular}{|c|c|c|c|c|c|c|}
\hline \multirow{2}{*}{$\begin{array}{c}\text { Factor-faktor yang } \\
\text { Memengaruhi Kejadian HIV }\end{array}$} & \multicolumn{2}{|c|}{ Kasus } & \multicolumn{2}{|c|}{ Control } & \multirow{2}{*}{ p-value } & \multirow{2}{*}{$\begin{array}{c}\text { OR } \\
\text { CI } 95 \%\end{array}$} \\
\hline & f & $\%$ & f & $\%$ & & \\
\hline \multicolumn{7}{|l|}{ Umur } \\
\hline 17-35 tahun & 12 & 38.7 & 16 & 51.6 & & 1.295 \\
\hline $36-55$ tahun & 19 & 61.3 & 15 & 48.4 & 0.586 & $0.789-2.127$ \\
\hline \multicolumn{7}{|l|}{ Jenis Kelamin } \\
\hline Laki-laki & 25 & 80.6 & 23 & 74.2 & 0.000 & 11.979 \\
\hline Perempuan & 6 & 19.4 & 8 & 25.8 & & 3.606-39.791 \\
\hline \multicolumn{7}{|l|}{ Pendidikan } \\
\hline Dasar & 1 & 3.2 & 2 & 6.5 & & \\
\hline Menengah & 28 & 90.3 & 25 & 80.6 & 0.503 & $0.031-5.151$ \\
\hline Tinggi & 2 & 6.5 & 4 & 12.9 & & \\
\hline \multicolumn{7}{|l|}{ Pekerjaan } \\
\hline Bekerja & 23 & 74.2 & 18 & 58.1 & & 2.076 \\
\hline Tidak bekerja & 8 & 25.8 & 13 & 41.9 & 0.283 & $0.709-6.085$ \\
\hline \multicolumn{7}{|l|}{ Status perkawinan } \\
\hline Belum kawin & 8 & 25.8 & 4 & 12.9 & & 0.426 \\
\hline Sudah Kawin & 23 & 74.2 & 27 & 87.1 & 0.335 & $0.113-1.599$ \\
\hline \multicolumn{7}{|l|}{ Perilaku Seks } \\
\hline Beresiko & 22 & 79 & 3 & 9.7 & & 12.815 \\
\hline Tidak beresiko & 9 & 29 & 28 & 90.3 & 0.000 & $5.509-94.478$ \\
\hline \multicolumn{7}{|l|}{ Perilaku penggunaan narkoba } \\
\hline Beresiko & 21 & 67.7 & 4 & 12.9 & & 10.175 \\
\hline Tidak beresiko & 10 & 32.3 & 27 & 87.1 & 0.000 & $3.893-51.607$ \\
\hline
\end{tabular}

Tabel di atas menunjukkan bahwa factor umurpada kelompok kasus terdapat sebanyak 12 responden $(38.7 \%)$ yang berumur 17-35 tahun dan 19 responden (61.3\%) yang berumur 36-55 tahun. Sedangkan pada kelompok kontrol terdapat sebanyak 16 responden $(51.6 \%)$ yang berumur 17-35 tahun dan 15 responden (48.4\%) berumur 36-55 tahun. Hasil uji statistik diperoleh nilai $\mathrm{p}=0.586$ artinya bahwa tidak ada pengaruh umur dengan kejadian infeksi HIV.

Pada factor jenis kelamin responden pada kelompok kasus terdapat sebanyak 6 responden $(19.4 \%)$ berjenis kelamin perempuan dan 25 responden berjenis kelamin laki-laki $(70.6 \%)$ sedangkan pada kelompok control terdapat sebanyak 8 responden $(25.8 \%)$ berjenis kelamin perempuan dan sebanyak 23 responden (74.2\%) berjenis kelamin laki-laki.
Hasil uji statistic diperoleh nilai $\mathrm{p}=0.000$ artinya ada pengaruh jenis kelamin dengan kejadian infeksi HIV. Dari hasil analisis juga diperoleh nilai $(\mathrm{OR}=11.979$; 95\% CI :3.606-39.791) artinya odds kejadian infeksi HIV pada responden yang berjenis kelamin laki-laki sebesar 11.979 kali lebih besar dibanding responden yang tidak mengalami infeksi HIV.

Pada faktor pendidikan pada kelompok kasus didapatkan sebanyak 1 responden $(3.2 \%)$ berpendidikan dasar, 28 responden $(90.3 \%)$ berpendidikan menengah dan 2 responden $(6.5 \%)$ berpendidikan tinggi. Sedangkan pada kelompok control terdapat sebanyak 2 responden $(6.5 \%)$ berpendidikan dasar, 25 responden $(80.6 \%)$ berpendidikan menengah dan 4 responden (12.9\%). Hasil uji statistic diperoleh nilai $\mathrm{p}=0.503$ artinya tidak ada pengaruh pendidikan dengan kejadian infeksi HIV. 
Factor pekerjaan pada kelompok kasus terdapat 23 responden $(72.4 \%)$ yang berkerja dan 8 responden $(27.6 \%)$ tidak bekerja. Sedangkan pada kelompok control terdapat 18 responden $(58.1 \%)$ berkerja dan 13 responden (41.9\%) tidak berkerja. Hasil uji statistic diperoleh nilai $\mathrm{p}=0.283$ artinya tidak ada pengaruh perkerjaan dengan kejadian infeksi HIV.

Factor status perkawinan pada kelompok kasus terdapat 8 responden (25.8\%) belum menikah dan 23 responden (74.2\%) sudah menikah.Sedangkan pada kelompok control terdapat 4 responden (12.9\%) belum menikah dan 27 responden (87.1\%) sudah menikah. Hasil uji statistic diperoleh nilai $\mathrm{p}=0.335$ artinya tidak ada pengaruh status perkawinan dengan kejadian infeksi HIV.

Factor perilaku seks pada kelompok kasus terdapat 9 responden (29\%) yang tidak berisiko dan 22 responden (71\%) yang berisiko.Sedangkan pada kelompok control terdapat 28 responden $(90.3 \%)$ yang tidak berisiko dan 3 responden (9.7\%) yang berisiko. Hasil uji statistic diperoleh nilai $\mathrm{p}=0.000$ artinya ada pengaruh perilaku seks berisiko dengan kejadian infeksi HIV. Dari hasil analisis juga diperoleh nilai (OR $=12.815 ; 95 \% \mathrm{CI}: 5.509-94.478$ ) artinya odds kejadian infeksi HIV pada responden yang berisiko sebesar 12.815 kali lebih besar dibanding responden yang tidak mengalami infeksi HIV.

Factor perilaku penggunaan narkoba pada kelompok kasus terdapat 10 responden (32.3\%) yang tidak berisiko dan 21 responden $(67.7 \%)$ yang berisiko.Sedangkan pada kelompok control terdapat 27 responden $(87.1 \%)$ tidak berisiko dan 4 responden $(13.9 \%)$ berisiko. Hasil uji statistic diperoleh nilai $p=0.000$ artinya ada pengaruh perilaku penggunaan narkoba dengan kejadian infeksi HIV. Dari hasil analisis juga diperoleh nilai $(\mathrm{OR}=10.175$; 95\%CI :3.89351.607) artinya odds kejadian infeksi HIV pada responden yang berisiko sebesar 10.175 kali lebih besar dibanding responden yang tidak mengalami infeksi HIV.

\section{Hasil Analisis Multivariat}

Model Regresi Logistik Tahap Pertama TerhadapKejadian Infeksi HIV pada Usia Produktif di Komite HIV AIDS Balige(n=62)Tahun 2017

\begin{tabular}{lccccc}
\hline \multirow{2}{*}{ Variabel } & B & Sig. & OR & \multicolumn{2}{c}{ 95\% C.I } \\
\cline { 2 - 6 } & & & & Lower & Upper \\
\hline Jenis kelamin & 2.524 &, 002 & 8.482 & 2.302 & 67.691 \\
Perilaku seks & 2.767 &, 004 & 10.913 & 2.361 & 107.242 \\
Perilaku penggunaan narkoba & 1.155 &, 176 & 3.175 & .595 & 16.947 \\
Constant & -2.845 &, 000 &, 058 & & \\
\hline
\end{tabular}

Tabel diatas menunjukkan bahwa variabel jenis kelamin, perilaku seks, memiliki nilai $\mathrm{p}<0,05$ sehingga dapat dimasukkan kedalam pemodelan selanjutnya sedangkan variabel perilaku penggunaan narkoba nilai $p>0.05$ sehingga variabel tersebut dikeluarkan dalam pemodelan selanjutnya.

Model Regresi Logistik Tahap Kedua Terhadap Kejadian Infeksi HIV pada Usia Produktif di Komite HIV AIDS Balige (n=62) Tahun 2017

\begin{tabular}{lccccc}
\hline \multirow{2}{*}{ Variabel } & B & Sig. & OR & \multicolumn{2}{c}{ 95\% C.I } \\
\cline { 2 - 6 } & & & & Lower & Upper \\
\hline Jenis kelamin & 2.716 &, 001 & 11.482 & 2.877 & 79.447 \\
Perilaku seks & 2.767 &, 000 & 15.217 & 4.779 & 146.602 \\
Constant & -2.689 &, 000 &, 058 & & \\
\hline
\end{tabular}


Berdasarkan tabel 4 menunjukkan bahwa kedua variabel yaitu variabel jenis kelamin dan perilaku seks memiliki nilai $\mathrm{p}<0.05$ artinya bahwa variabel jenis kelamin dan perilaku seks memengaruhi kejadian infeksi $H I V$. Dengan demikian maka variabel yang dominan memengaruhi terjadinya kejadian infeksi HIVadalah perilaku seks berisiko $(\mathrm{p}=0.000, \quad \mathrm{OR}=15.217,95 \% \mathrm{CI}$ : 4.779 - 146.602) yang berarti kejadian infeksi $H I V$ pada responden yang memiliki perilaku seks yang berisiko adalah 15.217 kali lebih besar dibanding yang perilaku seksnya tidak berisiko.

\section{Pengaruh Faktor Umur terhadap Kejadian Infeksi HIV Di Komite AIDS HKBP Balige}

Berdasarkan hasil penelitian yang dilakukan diperoleh hasil bahwa factor umur pada kelompok kasus terdapat sebanyak 12 responden $(38.7 \%)$ yang berumur 17-35 tahun dan 19 responden (61.3\%) yang berumur 36-55 tahun. Sedangkan pada kelompok kontrol terdapat sebanyak 16 responden $(51.6 \%)$ yang berumur 17-35 tahun dan 15 responden $(48.4 \%)$ berumur 3655 tahun. Hasil uji statistik diperoleh nilai $p$ $=0.586$ artinya bahwa tidak ada pengaruh umur dengan kejadian infeksi HIV.

Hasil penelitian ini juga sesuai dengan Amornkul, et al (2009) dalam penelitiannya di Kenyamenyebutkan bahwa umur yang lebih tua memiliki hubungan yang signifikandengan infeksi HIV. Penelitian USA Department of Health \& Human Services. (2012).) terhadap individuberusia 13-19 tahun di Amerika Serikat juga menyebutkan hal yang sama,yaitu umur lebih tua memiliki hubungan signifikan dengan infeksi HIV.

\section{Pengaruh Jenis Kelamin Terhadap Kejadian Infeksi HIV Pada Usia Produktif Di Komite AIDS HKBP Balige Tahun 2017}

Bertdasarkan hasil penelitian yang dilakukan diperoleh hasil jenis kelamin responden pada kelompok kasus terdapat sebanyak 6 responden (19.4\%) berjenis kelamin Perempuan dan 25 responden berjenis kelamin Laki-laki (70.6\%) sedangkan pada kelompok control terdapat sebanyak 8 responden $(25.8 \%)$ berjenis kelamin laki-laki dan sebanyak 23 responden (74.2\%) berjenis kelamin perempuan. Hasil uji statistic diperoleh nilai $\mathrm{p}=0.000$ artinya ada pengaruh jenis kelamin dengan kejadian infeksi HIV. Dari hasil analisis juga diperoleh nilai $(\mathrm{OR}=11.979$; 95\%CI :3.60639.791) artinya odds kejadian infeksi HIV pada responden yang berjenis kelamin lakilaki sebesar 11.979 kali lebih besar dibanding responden yang tidak mengalami infeksi HIV.

Hasil uji multivariat diperoleh nilai $(\mathrm{p}<0,025)$, artinya bahwa ada pengaruh jenis kelamin terhadap kejadian infeksi HIV. Dari hasil analisis juga diperoleh nilai $(\mathrm{OR}=$ $8.482,95 \%$ CI :2.302- 67.691) artinya odds kejadian infeksi HIV pada responden yang berjenis kelamin laki-laki adalah sebesar 8.482 kali lebih besar dibanding responden yang tidak mengalami infeksi HIV.

Secara umum data jumlah kasus HIV-AIDS yang dilaporkan cenderung lebih banyak terjadi di kalanagan laki-laki daripada perempuan. Data menunjukkan bahwa proporsi kasus AIDS pada laki-laki mencapai $78 \%$ dan perempuan sekitar $21 \%$ hal ini menunjukkan bahwa pengguna jarum suntik mayoritas adalah laki-laki juga pelangggan seks komersial secara umum kebanyakan laki-laki (Kemenkes, 2016).

\section{Pengaruh Tingkat Pendidikan Terhadap Kejadian Infeksi HIV Pada Usia Produktif Dikomite AIDS HKBP Balige Tahun 2017}

Berdasarkan hasil penelitian yang dilakukan diperoleh hasil factor pendidikan pada kelompok kasus didapatkan sebanyak 1 responden $(3.2 \%)$ berpendidikan dasar, 28 responden $(90.3 \%)$ berpendidikan menengah dan 2 responden $(6.5 \%)$ berpendidikan tinggi. Sedangkan pada kelompok control terdapat sebanyak 2 responden $(6.5 \%)$ berpendidikan dasar, 25 responden $(80.6 \%)$ berpendidikan menengah dan 4 responden (12.9\%). Hasil uji statistic diperoleh nilai 
$\mathrm{p}=0.503$ artinya tidak ada pengaruh pendidikan dengan kejadian infeksi HIV.

Pendidikan merupakan salah satu karakteristik individu yang menjadi variabel yang paling sering dihubungkan dengan kejadian suatu penyakit, termasuk IMS dan HIV. Hasil Survey IBBS pada penasun di Pokhara Valley pada tahun 2009 menunjukkan bahwa penasun yang tidak bisa baca-tulis beresiko 20 kali terinfeksi HIV dibandingkan penasun yang bisa baca-tulis (Chamroonsawasdi K, Insri N, Pitikultang S., 2011). Menurut UU RI No. 20 Tahun 2003 tentang sistim pendidikan nasional. Pendidikan adalah usaha sadar dan terencana untuk menyiapkan peserta didik melalui kegiatan pembimbing, pengajaran dan atau latihan bagi peranannya di masa yang akan datang. Peneliti berasumsi bahwa tingkat pendidikan mempengaruhi perilaku seseorang dalam berperilaku, bertindak.

\section{Pengaruh Pekerjaan Terhadap Kejadian Infeksi HIV Pada Usia Produktif Di Komite AIDS HKBP Balige Tahun 2017}

Berdasarkan hasil penelitian yang dilakukan diperoleh bahwa pekerjaan pada kelompok kasus terdapat 23 responden (72.4\%) yang berkerja dan 8 responden (27.6\%) tidak bekerja. Sedangkan pada kelompok control terdapat 18 responden (58.1\%) berkerja dan 13 responden (41.9\%) tidak berkerja. Hasil uji statistic diperoleh nilai $\mathrm{p}=0.283$ artinya tidak ada pengaruh perkerjaan dengan kejadian infeksi HIV. Berdasarkan pekerjaan didapatkan penderita HIV atau kelompok kasus rata-rata bekerja sebagai supir (29\%) dan sebagai pedagang (32.3\%), sedangkan pada kelompok kontrol memiliki pekerjaan petani (32.3\%).

Pekerjaan adalah suatu hubungan yang melibatkan dua pihak antara perusahaan dengan para pekerja/karyawan. Para pekerja akan mendapatkan gaji sebagai balas jasa dari pihak perusahaan, dan jumlahnya tergantung dari jenis profesi yang dilakukan. Keadaan sosial ekonomi, menuntut seseorang untuk mencari pekerjaan.

\section{Pengaruh Status Perkawinan terhadap Kejadian Infeksi HIV pada Usia Produktif di Komite AIDS HKBP Balige}

Berdasarkan hasil penelitian yang dilakukan diperoleh bahwa status perkawinan pada kelompok kasus terdapat 8 responden (25.8\%) belum menikah dan 23 responden (74.2\%) sudah menikah. Sedangkan pada kelompok control terdapat 4 responden (12.9\%) belum menikah dan 27 responden $(87.1 \%)$ sudah menikah. Hasil uji statistic diperoleh nilai $\mathrm{p}=0.335$ artinya tidak ada pengaruh status perkawinan dengan kejadian infeksi HIV.

Hasil Survey IBBS (Integrated Behaviour and Biological Survey) pada penasun di Pokhara Valley pada tahun 2009 menunjukkan bahwa prevalensi HIV pada penasun yang sudah menikah lebih tinggi $(6,6 \%)$ dibandingkan penasun yang belum menikah (1,7 \%) (Chamroonsawasdi K, Insri N, Pitikultang S, 2011).

\section{Pengaruh Perilaku seks beresiko dengan kejadian infeksi HIV Pada Usia Produktif Di Komite AIDS HKBP Balige}

Faktor perilaku seks berisiko pada kelompok kasus terdapat 9 responden (29\%) yang tidak berisiko dan 22 responden (71\%) yang berisiko.Sedangkan pada kelompok control terdapat 28 responden $(90.3 \%)$ yang tidak berisiko dan 3 responden $(9.7 \%)$ yang berisiko. Hasil uji statistic diperoleh nilai $\mathrm{p}=0.000$ artinya ada pengaruh perilaku seks berisiko dengan kejadian infeksi HIV. Dari hasil analisis juga diperoleh nilai $(\mathrm{OR}=$ 12.815; 95\% CI : 5.509-94.478) artinya odds kejadian infeksi HIV pada responden yang berisiko sebesar 12.815kali lebih besar dibanding responden yang tidak mengalami infeksi HIV.

Hasil uji multivariat diperoleh nilai $(\mathrm{p}<0,025)$, artinya bahwa ada pengaruh perilaku seks berisiko terhadap kejadian infeksi HIV. Dari hasil analisis juga diperoleh nilai $(\mathrm{OR}=10.913,95 \% \mathrm{CI}$ :2.361- 107.242) artinya odds kejadian infeksi HIV pada responden yang perilaku seks berisiko adalah sebesar 10.913 kali lebih 
besar dibanding responden yang tidak mengalami infeksi HIV.

Data menunjukkan bahwa hampir 90\% kasus HIV di seluruh dunia ditularkan melalui transmisi seksual.Banyak pasangan yang bukan suami istri tidak menggunakan kondom. Hasil Survey IBBS 2010 di Nigeria penggunaan kondom dengan pasangan seksual tetap cenderung lebih rendah dibandingkan dengan pasangan seks lainnya (Ditjen PP \& PL Kementrian Kesehatan RI, 2013).

\section{Hubungan Perilaku Penggunaan Narkoba Dengan Kejadian Infeksi HIV Pada Usia Produktif Di Komite AIDS HKBP Balige}

Berdasarkan hasil penelitian yang dilakukan diperoleh hasil bahwa perilaku penggunaan narkoba pada kelompok kasus terdapat 10 responden $(32.3 \%)$ yang tidak berisiko dan 21 responden (67.7\%) yang berisiko. Sedangkan pada kelompok control terdapat 27 responden (87.1\%) tidak berisiko dan 4 responden (13.9\%) berisiko. Hasil uji statistic diperoleh nilai $\mathrm{p}<0.05$ artinya ada pengaruh perilaku penggunaan narkoba dengan kejadian infeksi HIV.

Hasil uji multivariat diperoleh nilai $(\mathrm{p}<0,25), \quad$ artinya bahwa ada pengaruh perilaku penggunaan narkoba terhadap kejadian infeksi HIV. Dari hasil analisis juga diperoleh nilai $(\mathrm{OR}=3.175,95 \%$ CI $: 2.361$ 107.242) artinya odds kejadian infeksi HIV pada responden yang perilaku penggunaan narkoba yang berisiko adalah sebesar 3.175 kali lebih besar dibanding responden yang tidak mengalami infeksi HIV.

Hasil penelitian ini sejalan dengan hasilsurvei nasional perilaku berisiko di Amerika Serikat yang menyatakan bahwaanak muda yang menggunakan bahan berbahaya lebih cenderung terlibat dalamperilaku berisiko tinggi seperti hubungan seks tidak terlindungi.

\section{KESIMPULAN}

Berdasarkan hasil penelitian dan pembahasan melalui analisis faktor yang memengaruhi kejadian infeksi HIV diperoleh 3 faktor yang memengaruhi kejadian infeksi
HIV dan 4 faktor yang tidak memengaruhi kejadian infeksi HIV yaitu terdapat pengaruh jenis kelamin dengan OR $=11.979$ artinya odds kejadian infeksi HIV pada responden yang berjenis kelamin laki-laki sebesar 11.979 kali lebih besar dibanding responden yang tidak mengalami infeksi HIV. Terdapat pengaruh perilaku seks dengan $\mathrm{OR}=12,815$ artinya odds kejadian infeksi HIV pada responden yang bersiko sebesar 12,815 kali lebih besar dibanding responden yang tidak mngalami infeksi HIV.Terdapat pengaruh perilaku penggunaan narkobadengan $\mathrm{OR}=$ 10.175 artinya odds kejadian infeksi pada responden yang beresiko sebesar 10,175 kali lebih besar dibanding responden yang tidak mengalami infeksi HIV.

Tidak ada pengaruh umur dengan kejadian infeksi HIV dimana Hasil uji statistik diperoleh nilai $\mathrm{p}=0.586$ dan kenyataan dilapangan semua umur bisa terinfeksi HIV karena penularan HIV yang berbeda-beda walaupun penularannya didominasi oleh heteroseks.Tidak ada pengaruh pendidikan dengan kejadian infeksi HIV dimana hasil uji statistic diperoleh nilai $\mathrm{p}=0.503$ dan kenyataan dilapangan pendidikan semua pasien mayoritas pendidikan SMA.Tidakada pengaruh perkerjaan dengan kejadian infeksi HIV dimana hasil uji statistic diperoleh nilai $\mathrm{p}=0.283$. Tidak ada pengaruh status perkawinan dengan kejadian infeksi HIV dimana hasil uji statistic diperoleh nilai $\mathrm{p}=0.335$.

Berdasarkan hasil penelitian yang telah disajikan maka ada beberapa saran yang dapat disampaikan kepada beberapa pihak terkait yaitu

1. Bagi penderita HIV AIDS diharapkan untuk aktif dalam mengikuti program program yang dilperlukan penderita seperti program pendampingan terapi ARV (antiretroviral) maupun konseling yang akan memperpanjang kualitas hidup diberbagai aspek kehidupan baik aspek fisik,psiukoogis maupun sosial

2. Bagi Komite AIDS HKBP agar memberikan dukungan dan promosi kesehatan pada pasien ,keluarga dan 
masyarakat untuk mengurangi terjasinya isolasi ,harga diri dan ketakutan penderita HIV AIDS dan diskriminasi yang diraskan oleh penderita HIV AIDS serta perlunya pendekatan kepada tokoh agama dan tokoh masyarakat dalam melakukan promosi kesehatan

3. Keluargad an Pendamping, pasien HIV perlu mendapat perhatian dan dukungan dari masyarakat dan pemerintah, selain itu juga keluarga sangat berperan didalam memberikan motivasi bagi penderita HIV AIDS dalam menghjadapi situasi dan kondisi baik dukungan materi maupum agar penderita tidak terganggu dengan penyakit yang dialaminya

\section{DAFTAR PUSTAKA}

Chamroonsawasdi K, Insri N, Pitikultang S. (2011). Predictive factors of antiretroviral (ARV) drug adherence among people living with HIV/AIDS attending at Taksin hospital, Bangkok, Thailand. J Med Assoc Thail.

Ditjen PP \& PL Kementrian Kesehatan RI. (2013). Laporan Situasi Perkembangan HIV \& AIDS di Indonesia Triwulan IV Tahun 2013. Jakarta: Ditjen PP \& PL Kementrian Kesehatan RI.

Federal Ministry of Health. 2010. HIV Integretid Biological and Behavioral Survelance, Nigeria.

FHI.2009. Integretid Biological and Behavioral Survelance, Survey (IBBS) Among Injecting Drug User in Pokhara Velley. Nepal

Hardisman. 2009. HIV/AIDS di Indonesia: Fenomena Gunung es danperanan Pelayanan Kesehatan Primer. Jurnal Kesehatan Masyarakat Nasional, Vol.3 No. 5 April 2009

Kementrian Kesehatan. 2014 Profil Kesehatan Indonesia,Jakarta

Kementerian Kesehatan RI. 2016. Laporan Perkembangan HIV/AIDS Triwulan ke Liga 2016. Jakarta: Direktorat Jendral Pengendalian Penyakit dan Penyehatan Lingkungan.
Komite HIV/AIDS HKBP. (2017).

Menkes RI. 2013. Peraturan Menteri Kesehatan RI Nomor 12 Tahun 2013 tentang Jaminan Kesehatan.

UNAIDS. (2012). UNAIDS Report on the Global AIDS Epidemic.

USA Department of Health \& Human Services. (2012). Basic Information about HIV and AIDS. Atlanta (USA).

World Health Organization (WHO). (2012). Angka Kematian Bayi. Amerika. 